\title{
STRATEGI PEMBANGUNAN INDUSTRI PERTAHANAN PADA NEGARA KEPULAUAN GUNA MENDUKUNG PERTAHANAN NEGARA
}

\author{
Dede Rusdiana ${ }^{1}$, Yusuf Ali $^{2}$, Suyono Thamrin ${ }^{3}$, Resmanto Widodo ${ }^{4}$ \\ Universitas Pertahanan \\ Email: dede.rusdiana@idu.ac.id
}

\begin{abstract}
Abstrak
Indonesia merupakan negara kepulauan yang memiliki banyak potensi sumber daya. Potensi sumber daya nasional dapat digunakan untuk pembangunan ekonomi, salah satunya pembangunan industri pertahanan. Pembangunan industri pertahanan bukan hanya untuk kebutuhan alat pertahanan namun, juga dapat membantu masyarakat dalam roda perekonomian. Dalam mencapai tujuan negara optimalisasi negara kepulauan maka, perlu adanya perbaikan sistem yang mengarah pada kebijakan, dimana dalam penataan kebijakan diperlukan tahapan manjemen yaitu perencanaan (plan), pelaksanaan (do /action), dan penilaian hasil (evaluation). Kebijakan dilaksankan dengan menggunakan sumber daya nasional Permasalahan yang dihadapi untuk pembangunan industri pertahanan adalah belum optimalnya beberapa aspek sperti SDM, Teknologi, Kebijakan dll, sehingga penerapan strategi untuk industri pertahanan belum mampu mecapai kata ideal. Tujuan penulisan ini untuk mengilustratsikan strategi terbaik sehingga peran seluruh pemangku kepentingan dapat berjalan secara optimal.
\end{abstract}

Kata Kunci/Keywords : Strategi Pertahanan Kepulauan, Peran, pembangunan, industri pertahanan

\section{PENDAHULUAN}

Sejatinya Indonesia adalah negara kepulauan (airhipelago state) terbesar di dunia dengan 2/3 wilayahnya adalah lautan. Pengakuan dunia intemasional terhadap negara kepulauan tertuang pada Konvensi PBB tentang Hukum Laut (United Nations Convention on the Law of the Sea/UNCLOS) yang disahkannya di Montego Bay, Jamaika pada tahun 1982. Pengakuan dunia internasional terhadap konsepsi negara kepulauan dipengaruhi oleh berbagai kepentingan antar negara, khususnya negara-negara maritim besar yang ingin menancapkan hegemoninya di wilayah laut. Dengan demikian, disahkannya UNCLOS 1982, 
Indonesia yang berstatus sebagai negara kepulauan akan diuntungkan oleh ketentuan-ketentuan yang tertuang dalam Konvensi tersebut. Potensi dan peluang Indonesia negara kepulaan adalah pembangunan industri strategis pertahanan. Dengan pembangunan industri pertahanan yang mandiri pada negara kepulauan menjadikan Indonesia memiliki deterence effect, kekuatan yang dapat diperhitungkan dikancah Internasional

Industri pertahanan dibangun memerlukan rantai pasok yang baik dan optimal. Indonesia yang diuntungkan karena negara kepulauan yang potensi yang dimiliki dapat dimaksimalkan dengan baik untuk pembangunan industri pertahanan. Kebutuhannya adalah logistik militer menyerukan model manajemen rantai pasokan militer, di mana kesiapan berarti mewujudkan pengadaan, pasokan, pemeliharaan, dan distribusi yang optimal waktu. Manajemen rantai pasokan militer mengintegrasikan praktik bisnis yang digunakan di sektor komersial dengan kekuatan kesiapan militer dan visibilitas global.

Pencapaian optimalisasi industri pertahanan pada negara kepulau terdapat beberapa permasalahan pertama aspek regulasi pemerintah belum sepenuhnya mengembangkan visi yang menjadi poros maritim dunia karena pembangunan ekonomi masih bersegmen land based oriented. Kedua aspek teknologi untuk pemanfaatan SDA laut yang masih renddah dengan terbukti masih belum pasti data potensi kekayaan alam laut Indonesia. ketiga aspek SDM atau sember daya manusia yang belum sepenuhnya menguasai ilmu kelautan. Keempat keamanan pengawasan laut belum terintegrasi dan masih tersebar diberbagai instansi, permasalahan diwilayah perbatasan laut. Kelima aspek undang-undang yang masih tumpang tindih yang masih belum memaukkan urusan udara, laut dan darat sebagai satu kesatuan. Dan keenam aspek kelembagaan yang koordinasi dan pengawasan yang tidak efisien terkesan berjalan sendiri-sendiri tidak terorganisasi dengan baik. Permasalahan pembangunan negara kepulauan yang mandiri dan merdeka menjadi terhambatnya pembangunan industri pertahanan.

Dalam mencapai tujuan negara optimalisasi negara kepulauan maka, perlu adanya perbaikan sistem yang mengarah pada kebijakan, dimana dalam penataan kebijakan diperlukan tahapan manjemen yaitu perencanaan (plan), pelaksanaan 
(do /action), dan penilaian hasil (evaluation). Kebijakan dilaksankan dengan menggunakan sumber daya nasional (Yugiantoro, 2014). Dalam tulisan ini penulis mencoba menganalisis optimalisasi negara kepulauan dalam pembangunan pertahanan yang mengarah pada pembangunan industri pertahanan. Dengan tulisan ini mencoba untuk menerapkan konsep strategis dalam optimalisasi negara kepulauan dalam pembangunan industri pertahanan.

Penelitian ini membahas tentang fenomena permasalahan negara kepulauan dalam pembangunan industri pertahanannya berdasarkan pendekatan kualitatif. Pengumpulan data dilakukan melalui observasi dan studi pustaka penelitian terdahulu. Permaslahan negara kepulauan dalam berbagai aspek perlu dilakukan pembenahan yang dapat mengintegrasikan berbagai kepentingan dan peran sehingga menciptakan optimalisasi negara kepulauan dalam pembangunan industri pertahanan. Oleh karenanya penulis secara sistimatis akan mengumpulkan data-data yang diperlukan dan kemudian mendeskrisipkannya (Moeleong, 2007). Data dari proses penggalian sumber data melalui studi kepustakaan (Library research) berupa buku-buku, jurnal atau artikel, arsip, surat kabar, dan internet, untuk selanjutnya dianalisis dengan menggunakan teori pendukung untuk menentukan strategi dan kebijakan apa yang diambil dengan menelusuri potensi sumber daya dari sebuah negara kepulauan.

Landasan teori yang dipergunakan meliputi teori serta konsep yang dapat dijadikan dasar untuk pembuatan sintesis (kesimpulan) beserta indikator-indikator yang dituliskan pada bagian akhir dari sebuah penelitian

\section{Strategi}

Definisi strategi dikemukakan oleh beberapa ahli. Menurut Chandler (1962), strategi merupakan alat untuk mencapai tujuan perusahaan dalam kaitannya dengan tujuan jangka panjang, program tindak lanjut, serta prioritas alokasi sumber daya. Strategi juga dapat didefinisikan sebagai respons-secara terus menerus maupun adaptif-terhadap peluang dan ancaman eksternal serta kekuatan dan kelemahan internal yang dapat memengaruhi organisasi. (Mintzberg:1991, Steiner dan Miner: 1977). 
Menurut David (2011), Strategi adalah sarana bersama dengan tujuan jangka panjang yang hendak dicapai. Strategi bisnis mencakup ekspansi georafis, diversifikasi, akusisi, pengembangan produk, penetrasi pasar, pengetatan, divestasi, likuidasi, dan usaha patungan atau joint venture. Strategi adalah aksi potensial yang membutuhkan keputusan manajemen puncak dan sumber daya perusahaan dalam jumlah besar. Jadi strategi adalah sebuah tindakan aksi atau kegiatan yang dilakukan oleh seseorang atau perusahaan untuk mencapai sasaran atau tujuan yang telah di tetapkan.

Strategi merupakan sesuatu yang dibutuhkan dan terdapat setidaknya 8 langkah atau tahapan yang bisa membantu organisasi dalam berpikir dan bertindak secara sistematis. Langkah-langkah tersebut adalah sebagai berikut:

a. Memprakarsai dan menyepakati proses perencanaan strategis.

b. Mengidentifikasikan mandat organisasi.

c. Memperjelas misi dan nilai-nilai organisasi.

d. Menilai lingkungan eksternal: peluang dan ancaman.

e. Menilai lingkungan internal: kekuatan dan kelemahan.

f. Mengidentifikasikan isu strategis yang dihadapi organisasi.

g. Merumuskan strategi untuk mengelola isu.

h. Menciptakan visi organisasi yang efektif bagi masa depan

\section{Pembangunan}

Teori pembangunan dalam ilmu sosial dapat dibagi ke dalam dua paradigma besar, modernisasi dan ketergantungan (Lewwellen 1995, Larrin 1994, Kiely 1995 dalam Tikson, 2005). Paradigma modernisasi mencakup teori-teori makro tentang pertumbuhan ekonomi dan perubahan sosial dan teoriteori mikro tentang nilai-nilai individu yang menunjang proses perubahan. Paradigma ketergantungan mencakup teori-teori keterbelakangan (under-development) ketergantungan (dependent development) dan sistem dunia (world system theory) sesuai dengan klasifikasi Larrain (1994).

Sedangkan Tikson (2005) membaginya ke dalam tiga klassifikasi teori pembangunan, yaitu modernisasi, keterbelakangan dan ketergantungan (Kumba, 2019). Dari berbagai paradigma tersebut itulah kemudian muncul berbagai versi 
tentang pengertian pembangunan. Sehingga teori pembangunan adalah suatu upaya terkoordinasi untuk menciptakan alternatif yang lebih banyak secara sah kepada setiap warga negara untuk memenuhi dan mencapai aspirasinya yang paling manusiawi (Nugroho dan Rochmin Dahuri, 2004). Pembangunan juga merujuk pada proses untuk melakukan perubahan, sehingga pengertian dari pembangunan sendiri dapat berbeda-beda sesuai dengan kajian yang diambil. Dasar pengertian pembangunan adalah ketergantungan adanya proses perubahan.

Penelitian ini mengarah pada pembangunan industri pertahanan sehingga perlu diketahui tujuannya. Sehingga tidak bisa terlepas secara umum dari tujuan pembangunan industri itu sendiri,sebagai berikut:

a. mewujudkan Industri nasional sebagai pilar dan penggerak perekonomian Nasional;

b. mewujudkan kedalaman dan kekuatan struktur Industri;

c. mewujudkan Industri yang mandiri, berdaya saing, dan maju, serta Industri Hijau;

d. mewujudkan kepastian berusaha, persaingan yang sehat, serta mencegah pemusatan atau penguasaan Industri oleh satu kelompok atau perseorangan yang merugikan masyarakat;

e. membuka kesempatan berusaha dan perluasan kesempatan kerja;

f. mewujudkan pemerataan pembangunan Industri ke seluruh wilayah Indonesia guna memperkuat dan memperkokoh ketahanan Nasional;

g. meningkatkan kemakmuran dan kesejahteraan masyarakat secara berkeadilan.

Pembangunan industri juga perlu memperhatikan keberlanjutan lingkungan sekitar, dengan adanya pertimbangan aspek lingkungan dapat mewujudkan keberlanjutan pembangunan dan kelangsungan hidup masyarakat. Hal tersebut telah diatur dalam juga UU RI No. 3 Tahun 2014 pasal 3 ayat 3 mengenai Industri Hijau. Industri Hijau berdasarkan UU RI No. 3 Tahun 2014 pasal 1 ayat 3 adalah Industri yang dalam proses produksinya mengutamakan upaya efisiensi dan efektivitas penggunaan sumberdaya secara berkelanjutan 
sehingga mampu menyelaraskan pembangunan Industri dengan kelestarian fungsi lingkungan hidup serta dapat memberikan manfaat bagi masyarakat.

\section{Peran}

Robert Linton seorang antropolog mengembangkan teori peran yang menggambarkan interaksi sosial terminologi aktor-aktor yang bermain sesuai dengan yang telah ditetapkan oleh budaya. Harapan-harapan peran akan menuntun seseorang untuk berperilaku dalam kehidupan sehari-hari. Menurut teori peran, seseorang memiliki peran tertentu misalnya sebagai dokter, mahasiswa, orang tua, pengusaha dan lain sebagainya. Oleh karena itu, seseorang tersebut diharapkan berperilaku sesuai dengan peran tersebut. Pada hakikatnya, teori peran menekankan sifat individu sebagai pelaku sosial. Teori ini adalah teori perilaku sesuai dengan posisi yang ditempatinya di lingkungan kerja dan masyarakat. Dihapakan ketika individu menduduki sebuah posisi dalam lingkungan kerjanya, individu tersebut dituntut dapat berinteraksi dengan hal lain atau individu lain sebagai bagian dari pekerjaannya. Seperangkat aktivitas dalam lingkungan pekerjaan mengandung beberapa peran dari individu yang menduduki suatu posisi.

Biddle dan Thomas (1966) membagi tiga indikator tentang perilaku dalam kaitanya dengan peran sebagai berikut :

a. Harapan tentang peran (expectation)

Harapan tentang peran adalah harapan- harapan orang lain tentang perilaku yang pantas, yang seharusnya ditunjukkan oleh seseorang yang mempunyai peran tertentu. Harapan tentang perilaku ini bisa berlaku umum, bisa merupakan harapan dari segolongan orang saja, dan bisa juga merupakan harapan dari satu orang tertentu.

b. Norma (norm)

Secord dan Backman berpendapat bahwa, norma hanya merupakan salah satu bentuk harapan. Secord dan Backman membagi jenis- jenis harapan sebagai berikut:

1) Harapan yang bersifat meramalkan (anticipatory), yaitu harapan tentang suatu perilaku yang akan terjadi. 
2) Harapan normatif (role expectation), yaitu keharusan yang menyertai suatu peran.

c. Wujud perilaku dalam peran (performance)

Peran diwujudkan dalam perilaku oleh aktor. Wujud perilaku dalam peran ini nyata dan bervariasi, berbeda- beda dari satu aktor ke aktor yang lain. Variasi tersebut dalam teori peran dipandang normal dan tidak ada batasnya. Teori peran tidak cenderung mengklasifikasikan istilah-istilahnya menurut perilaku khusus, melainkan berdasarkan klasifikasinya pada sifat asal dari perilaku dan tujuannya (motivasinya). Sehingga, wujud perilaku peran dapat digolongkan misalnya kedalam jenis hasil kerja, hasil sekolah, hasil olahraga, pendisiplinan anak, pencari nafkah, pemeliharaaan ketertiban, dan lain sebagainya.

\section{Military Industrial Complex}

Military Industrial Complex (MIC) ini muncul dan di utarakan oleh Dwigh Eisenhower pada tahun 1961 mantan seorang militer dan presiden AS, MIC adalah sebuah rangkaian kerjasama strategis yang melibatkan pemerintah, dunia usaha, perbankan, industri pertahanan, pensiunan dan analis studi strategis, yang terikat dalam sebuah skema pembagian peran.

Industri pertahanan bukan hanya pembangunan pertahanan namun sebagai bentuk langkah konkrit yang dapat mengerakan perekonomian suatu negara. MIC dibentuk dengan tujuan untuk menciptakan industri yang mampu mengarah pada;

a. Penguasaan terhadap teknologi militer yang berbasis informasi dan teknologi ;

b. Kesiapan menggerakkan potensi militer yang dimiliki sebagai alat pamaksa ;

c. Ketahanan ekonomi teknologi dan perangkat persenjataan mempengaruhi orientasi pertahanan dan keamanan Negara,

d. Menciptakan kader bela negara terutama untuk pertahanan dan keamanan yang memprioritaskan pembelian perangkat perang 
Industri militer atau pertahanan merupakan kekuatan untuk memprioritaskan hubungan dalam negeri dan luar negeri. Selain itu anggaran dana yang begitu besar akan dialihkan dari program-program sosial untuk menyokong tambahan senjata dan pembangunan kekuatan dengan membuka ribuan lapangan pekerjaan, semakin memberikan pengaruh yang besar bagi industri militer karena bagi perusahaan industri militer memiliki keuntungan bagi masyarakat luas.

\section{PEMBAHASAN}

Kedaulatan dan keamanan negara menjadi isu yang jauh lebih kompleks, khususnya karena Indonesia merupakan negara kepulauan (archipelagic state). Mempertahankan dan melindungi kuasa dan wibawa di dalam wilayah nasional hanya merupakan sebagian saja dari apa yang seharusnya dibela, diperjuangkan dan dibina. Ketergantungan besar, dan akan semakin besar, pada perairan internasional sebagai konsekuensi dari interdependensi perdagangan dunia menyebabkan Indonesia perlu kemampuan untuk menjangkau kawasan ekonomi eksklusif sejauh 200 mil laut dari garis-garis terluar. Sebagai negara pihak dalam UNCLOS, Indonesia dihadapkan pada kemungkinan untuk menggunakan sumberdaya kelautan dan maritim tetapi juga dihadapkan pada kerawanan sea lanes of communication dan corong-corong laut dari berbagai bentuk tantangan termasuk lalu lalang kapal selam nuklir, intrusi tak terkendali, dan keselamatan pelayaran laut dan udara. Kedaulatan wilayah tidak lagi dapat ditafsirkan hanya sebagai hak untuk menguasai dan tangungjawab untuk melindungi wilayah nasional melainkan juga hak untuk memperoleh jaminan atas akses.

Permasalahan terkait kelautan memerlukan teknologi yang tepat agar dapat menjaga kedaulatan negara secara optimal. Pencapaian tersebut tidak terlepas dari upaya pembangunan industri pertahanan khususnya pada Negara kepulauan. Pembanguanan industri pertahanan perlu mendapat dukungan dari semua pihak. Permasalahan yang ada saat ini yaitu masih terdapatnya tumpang tindih berbagai aspek mulai dari sumber daya manusia hingga kebijakan serta kurangnya manajemen pengelolaan industri pertahanan yang baik. 
Pembangunan industri pertahanan dihadapkan pada tujuan mewujudkan pemerataan pembangunan industri ke seluruh wilayah Indonesia guna memperkuat dan memperkokoh ketahanan Nasional. Saat ini, proses pembangunan masih tersegmentasi pada kawasan pulau Jawa, sehingga perlu adanya perencanaan pada daerah-daerah lain. Pembangunan dilakukan dengan melibatkan peran semua pihak guna mendukung pertahanan negara.

Negara Indonesia sebagai negara yang berdaulat dengan luas wilayah lebih dari 1.906.240 km2 harus memiliki Alutsista khusus sebagai sebuah negara kepulauan. Membeli Alutsista dari negara lain tidak ubahnya memaksa untuk memahami karakteristik Alutsista khas negara lain yang belum tentu sesuai dengan karakteristik bangsa kita. Dampaknya adalah munculnya kerawanan atas kedaulatan wilayah oleh negara lain misalnya pelanggaran batas laut. Dengan memiliki Alutsista modern yang sesuai dengan karakteristik bangsa, maka pertahanan negara tidak perlu dikhawatirkan. Untuk itu, pembangunan industri pertahanan memerlukan dukungan pemeliharaan, alih teknologi, integrasi dan yang terutama adalah penguasaan penuh terhadap alutsista yang digunakan baik secara teknologi maupun secara non-teknis. Dengan demikian secara perlahan Indonesia dapat mengurangi ketergantungan kepada luar negeri dalam hal pengadaan Alutsista (Adang \& Arwin. 2010).

Pertahanan negara harus mampu menjadi pilar utama bagi penangkalan (deterrence) maupun jaminan (assurance) atas kedaulatan itu. Kekuatan pertahanan harus ditempatkan dalam konteks gelar kekuatan pertahanan negara. Ukuran kuantitatif penting, namun harus mencerminkan realitas, apalagi jika ukuran itu sekedar bersifat statis seperti jumlah pasukan per penduduk, jumlah pesawat/kawasan dan lain-lain, sekalipun ukuran itu tentu mencerminkan sesuatu dan dapat mejadi salah satu ukuran kekuatan tempur. Peringkat Indonesia, seperti antara lain disinyalir oleh Global Fire Power seperti dikutip di atas, boleh jadi memang sudah cukup meyakinkan pada tataran komparatif tetapi tidak mencerminkan kebutuhan Indonesia sebagai negara kepulauan, khususnya ketika force-to-area rasio memang jauh lebih kompleks dibanding negara-negara kontinen/daratan. 
Pembangunan Industri pertahanan dicanangkan oleh Pemerintah dalam rangka mengembangkan postur pertahanan untuk meningkatkan daya tangkal (deterrence) dalam menghadapi berbagai ancaman. Sehingga, masterplan industri pertahanan perlu dibuat sebagai pedoman guna menciptakan kemandirian industri pertahanan.

\section{Gambar}

Master plan Pertahanan

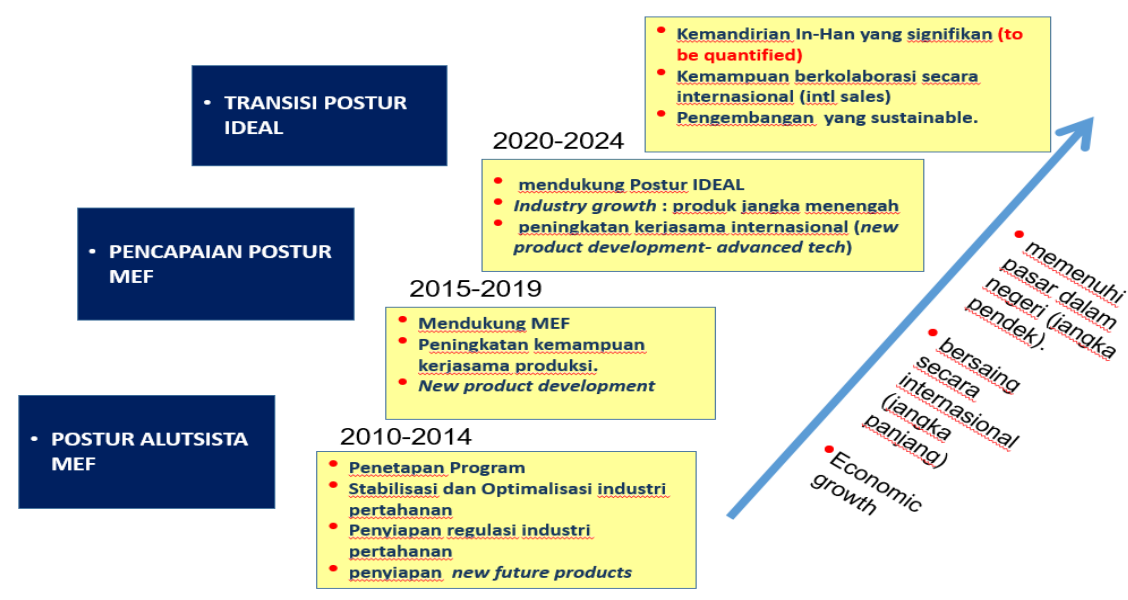

Sesuai gambar tersebut, maka untuk mencapai postur yang ideal perlu kemandirian dan kemampuan berkolaborasi secara internasional serta harus berperan aktif untuk membentuk sinergi dengan berbagai pihak. Salah satu bentuk sinergi yaitu mengembangkan sistem kebijakan pita pengaman nasional (national security belt) yang menghubungkan titik-titik pulau NKRI terdepan. Saat ini, terdapat 92 pulau yang merupakan pulau-pulau terdepan (terluar). Dalam konteks politik, pertahanan, dan ekonomi titik-titik pulau tersebut diharapkan dapat dihubungkan dengan satu kebijakan yang namanya national security belt. Pada tiap-tiap titik pulau itu harus didesain ada sentra kegiatan guna mendukung pembangunan pertahanan negara. Potensi ekonomi, sosial,politik, budaya, demografi dan sumber daya alam yang tersebar di seluruh wilayah Indonesia perlu diintegrasikan menjadi sebuah peta kekuatan pertahanan dari Sabang sampai Merauke. 
Sinergi penyelenggaraan pemerintahan di daerah serta kegiatan sosial ekonominya adalah sebuah kesisteman berupa pelayanan pemerintahan yang memadai, kesehatan, pendidikan maupun perekonomian. Pembangunan industri pertahanan dapat menjadi bagian untuk pergerakan ekonomi di daerah dengan produk-produk yang dapat digunakan oleh daerah perbatasan dan pesisir misalnya produk kapal yang dapat digunakan nelayan untuk menangkap ikan. Ada sebuah fakta bahwa hasil tangkapan ikan nelayan-nelayan Pulau Sebatik dikeringkan dan hasilnya dijualnya ke Tawau, Malaysia dengan alasan jarak ke Tawau hanya setengah jam. Apabila ikan tersebut dijual ke Nunukan memerlukan waktu tempuh 3,5 jam. Jadi biayanya lebih mahal. Namun fakta yang lebih menyedihkan lagi adalah bahwa nelayan-nelayan tersebut dibiayai oleh orang-orang Tawau Malaysia. Jadi penting kiranya memberikan kemudahan akses kepada masyarakat yang hidup di daerah perbatasan untuk merasa bahwa mereka merupakan bagian integral dari Negara Kesatuan Republik Indonesia. Salah satu hal yang perlu dilakukan adalah memberikan jejak Indonesia pada setiap aktivitas kesehariannya. Artinya bahwa kemudahan akses terhadap peralatan yang dibutuhkan benar-benar dapat diterima dan dinikmati oleh masyarakat tersebut.

Selanjutnya adalah upaya mengoptimalkan peran dan sinergi pengembangan insitusi atau kelembagaan yang efektif serta menerapkan sistem koordinasi lintas institusi. Penerapan Undang-undang Nomor 23 Tahun 2019 Tentang Pengelolaan Sumber Daya Nasional untuk Pertahanan Negara, sebagai bentuk dukungan pemerintah terhadap adanya optimalisasi dalam pertahanan negara. Bentuk peran kebijakan ini yaitu mobilisasi adalah tindakan pengerahan dan penggunaan secara serentak Sumber Daya Nasional serta Sarana dan Prasarana Nasional yang telah dipersiapkan dan dibina sebagai komponen kekuatan Pertahanan Negara untuk digunakan secara tepat, terpadu, dan terarah bagi penanggulangan setiap ancaman, baik dari luar negeri maupun dari dalam negeri yang membahayakan persatuan dan kesatuan bangsa serta kelangsungan hidup bangsa dan Negara Kesatuan Republik Indonesia.

Meskipun dalam undang-undang tersebut lebih mengarah pada pembangunan kekuatan SDM dan tidak menyebutkan industri pertahanan, namun 
setidaknya pembangunan SDM yang baik dapat menjadi titik awal untuk pembangunan industri pertahanan. Mengikuti perkembangan isu-isu baru kelautan merupakan bagian proses dan mengelola laut. Segenap isu terkait dengan isu kelautan sesungguhnya tersebar menjadi bagian kewenangan beberapa departemen. Hal ini menjadi kendala dalam proses koordinasi yang tidak singkron dan cenderung memunculkan ego sektoral. Tujuan pembangunan industri pertahanan pada daerah- daerah yaitu (1) sebagai bentuk kolaborasi dalam produk pertahanan melalui joint partnership, joint venture, dan coproduction, serta melihat prospek terciptanya skala ekonomi (economic scale) pada bentuk kolaborasi, (2) memperkenalakan produk pertahanan bukan hanya untuk pertahanan namun juga untuk membantu masyarakat daerah perbatasan dan pesisir, (3) mendukung negara dalam industri dan perdagangan sekaligus upaya mensosialisasikan pentingnya pemahaman di sektor pertahanan, (4) meningkatkan teknologi dan tingkat kompetisi industri dalam pertahanan dan industri dual-use, (5) memberikan insentif yang akan memberi bantuan pada pertumbuhan industri pertahanan di Indonesia. selain itu penetapan industri pertahanan daerah pesisir maupun perbatasan menunjukkan bahwa pembangunan pertahanan diperuntukan bagi semua kawasan kepulauan dan dapat digunakan untuk banyak kalangan secara bersama-sama guna mengembangkan dan memproduksi alat pertahanan.

Potensi wilayah kepualau di Indonesia juga berbeda-beda sehingga perlu adanya peran penting dalam pemetaan wilayah untuk mengetahui secara pasti potensi yang dimiliki oleh setiap daerah. Pembangunan industri pertahanan yang didirikan pada setiap wilayah perlu juga meperhitungkan rantai pasok. Misalnya pada daerah Morowali terdapat sumber daya alam nikel, maka perusahananperusahaan pertahanan yang membutuhkan nikel dapat diarahkan untuk memasok bahan baku dari daerah Morowali tanpa harus mengimpor dari luar negeri. Selain Morowali, misalnya pada daerah Bangka merupakan sumber penghasil timah dan almunium. Potensi ini sangat cocok untuk bahan dari pembuatan pesawa. Maka yang perlu disiapkan adalah kesiapan SDM dan teknologi sehingga mampu mengambil dan mengolah bahan baku produksi dalam negeri. 
Indonesia juga dikenal sebagai penghasil kelapa sawit. Dari potensi ini harusnya mampu digunakan oleh industri pertahanan guna sumber bahan bakar untuk kendaraan-kendaraan berat dan alat pertahanan lainnya. Oleh karena itu, penting kiranya mengembangkan strategi tentang bagaimana mengembangkan kelembagaan yang efektif dalam menangani seluruh permasalahan negara kepulauan disertai dengan manajemen yang baik. Manajemen dalam konteks ini adalah yang dapat memperhatikan tentang bagaimana melakukan pembinaan sumberdaya manusia, pembinaan pendanaannya, pembinaan materialnya, koordinasinya, metodologi dan sebagainya itu.

\section{KESIMPULAN}

Dari uraian dan penjelasan diatas dapat diambil kesimpulan sebagai berikut :

1. Pertahanan Kepulauan Indonesia membutuhkan strategi pembangunan industri pertahanan yang terintegrasi dengan baik, sehingga kemampuan produk industri tersebut dapat digunakan untuk menghadapi setiap ancaman yang datang baik dari dalam maupun luar negeri.

2. Industri Pertahanan dalam negeri sangat membutuhkan peran semua pihak yang terintegrasi sehingga meminimalisir kegiatan yang tumpang tindih antar Kementerian/Lembaga dalam rangka menciptakan kemandirian industri pertahanan yang sesuai dengan karakteristik Indonesia sebagai negara kepulauan.

3. Peran Pemerintah pusat, Kementerian/ Lembaga dan sampai ke tingkat pemerintah daerah untuk pemanfaatan sumber daya nasional dalam mempersiapkan pembangunan industri pertahanan sebagai upaya yang dipersiapkan guna membantu komponen utama pertahanan negara dalam menghadapi ancaman pada masa damai dan masa perang/krisis. 


\section{DAFTAR PUSTAKA}

Ahmad, Adang \& Arwin Datumaya. (2010). Membangun Sinergi dan Kolaborasi Tiga pilar Nasional Menuju Kemandirian Sistem Pertahanan Keamanan Nasional. SATRIA Studi Pertahanan Vol 6(2).

Biddle, B.J dan Thomas, E.J, (1966). Role Theory: Concept and Research. NewYork. : Wiley

Bryson, Jhon M. (2007). Perencanaan Strategis Bagi Organisasi Sosial. Cet 8. Yogyakarta: Pustaka Pelajar

Digdowiseiso, Kumba. (2019). Teori Pembangunan. Jakarta: Lembaga Penerbitan Universitas Nasional

Mintzberg, H., \& Quinn, J. (1991). The Strategy Process: Concept, Context, and Cases. New Jersey: Englewood Cliffs.

Puspitawati, Dhiana. (2014). Desentralisasi Pengelolaan Wilayah Pesisir Dan Lautan dalam Kerangka Prinsip Negara Kepulauan. ARENA HUKUM Volume 7, Nomor 2, pp 151-302

Stanger, Allison \& Mark Eric Williams. Private Military Corporations: Benefits and Costs of Outsourcing Security

Teuku Rezasyah. (2012). Politik Luar Negeri Republik Indonesia: Dari Prespektif Ideal Hingga Praktis yang diakses dari pustaka.unpad.ac.idwpcontentuploads200905politik_luar_negeri_republik_indonesia.pdf. hal. 2 . Pada tanggal 18 April 2021.

Undang-undang Nomor 23 Tahun 2019 Tentang Pengelolaan Sumber Daya Nasional Untuk Pertahanan Negara

Wahyudi, yuda \& Mahifal. (2013). Strategi Pembangunan Negara Kepulauan. WAWASAN TRIDHARMA: Scientific Magazine of Kopertis Wilayah IV No.6 No.2009/SK/DITJEN PPG/STT/ 1994; ISSN 021 5-8256

Yusgiantoro, Purnomo. (2014). Ekonomi Pertahanan Teori dan Praktik. Jakarta: PT.Gramedia Pustaka Utama 